\section{Brain function}

\section{S A Greenfield}

\section{The interaction between genes and environment}

$M$ any have alluded to the importance of the environment on the developing brain. As a neuroscientist, I root and endorse that view in the bump and grind of brain cells. You are born with most of the brain cells you will ever have. It is the growth of the connections between the brain cells that accounts for the growth of the brain after birth. What is exciting is that the environment will influence the configuration of those connections. So even if you are a clone-that is, an identical twin-you will have a unique pattern of brain cell connections.

Genes play a part. I do not wish to denigrate genes; I merely wish to put them, despite all the hype, literally in their place. Genes make proteins, which are important biochemical baggage for brain cell circuits to work. But they are not a one-off; they are constantly being activated or switched off according to the caprices of the environment, whether it is the micro-milieu of the brain itself or the external environment in which you are moving.

Hence you will appreciate that it is impossible to make the old and hackneyed division between nature and nurture. Rather we should think of a dialogue, an interaction, where there is no genetic controller orchestrating events but a ceaseless interaction between the environment and the molecular landscape of the brain. What is important is that the environment can determine how that landscape looks.

Let me take, for example, what may seem to be a counter-example. The condition Huntingdon's chorea-named after the Greek for "to dance" - is socalled because it is characterised by a

This is the text of a speech made to the House of Lords on 26 March 2003 by Baroness Greenfield in a debate on "Children and Parents". The session also featured the maiden speeches of the present and former Archbishops of Canterbury. It has had references to "My Lords" removed to avoid confusing our readers. wild involuntary flinging of the limbs in a grotesque form of dance. The reason for choosing this example is that it is one of the few brain disorders that can be attributed to a single rogue gene. However, we know that even in mice that have had their genes tweaked so that they have the single rogue genethey have the mouse equivalent of this movement disorder-the onset and severity of the disease can be offset. It can be made much more moderate and come along much later in their lives if they have a so-called enriched environment. For a mouse this means a few little ladders and toys with which they interact.

We know that adult rats exposed to ladders and toys and a so-called enriched environment will have more connections in their brains. The brain cells have more branches, which enable the brain cells to form more connections than their counterparts kept in simpler conditions. If this is the case for adult rodents playing with a few little ladders and wheels, how much more for the human brain?

The most marvellous aspect of being born a human being is that you are freed-up more than any other animal from the tyranny of your genes; you are freed-up from having to obey instinct. That is why we, as a species, occupy more ecological niches than any other species on earth. It is because we are supremely able, compared to any other species, to learn that we are freed-up from the demands of instinct. And if you have individual experiences, guess what? You become an individual.

We are born into the world, in the words of the nineteenth century psychologist William James, "as a booming, buzzing confusion". We evaluate it in terms of its primary sensory qualitieshow sweet, how fast, how cold, how bright-but gradually these abstract sensations will coalesce into faces and objects. Gradually, as we get language, those faces and objects will acquire a name, a label. If they mean something to us they will feature in certain events in our lives that become memories. The more they feature, the more connections they will trigger and the more deep their significance to us will become. brains; we develop a mind. It is this learning, this ability to see one thing in terms of another, that I regard as understanding. Far from being some airy-fairy alternative to the squalor of the physical brain, I see the mind as the personalisation of the brain. It is these personalised connections, sadly, which can be dismantled by conditions such as Alzheimer's disease. As you may know, in such degenerative conditions the patient will gradually recapitulate childhood; gradually the world will mean less and less and gradually the patient will retreat back into the booming and buzzing confusion, where even people and objects that were very dear and close to the patient are no longer recognised.

The point I am trying to make is that the competence of our brains, of our mental abilities, rests on the integrity and the extent and number of our brain connections. It is these connections, which, in turn, are dependent on the experiences we have in the world.

You may have heard of a fascinating study recently undertaken with London taxi drivers. It is of course well known that London black-cab drivers learn the "knowledge"; they have to remember all the streets of London in order to navigate about without using references. This is a huge burden on that particular ability, but it turns out that the brain scans of London taxi drivers, when compared with people of like age, show an enhanced area related to memory. That part of the brain is larger in taxi drivers than it is in other people. The fact is not lost on our London taxi drivers, most of whom have heard of the study. It is not the case that London taxi drivers are predisposed to having larger areas in this part of their brains. The longer someone works as a taxi driver, the more marked is the difference.

You do not have to be a London taxi driver to display plasticity in this way. It

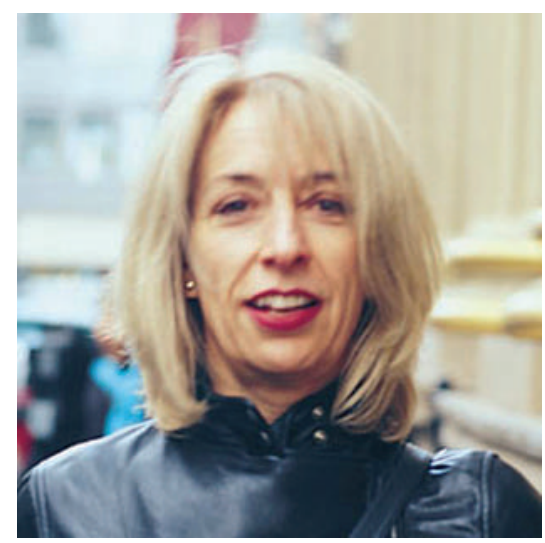

Baroness Greenfield. 
Sir David Hall, recent past president of the RCPCH, spotted this speech and sent a copy to $A D C$. $\mathrm{He}$ thought it was an elegant summary of the thinking behind SureStart and parenting programmes. For other speeches given in the same debate, see Hansard-Children and Parents, 646 (26.3.03) 888-90.

Susan Greenfield is a neuroscientist who is Director of the Royal Institution of Great Britain and is senior research fellow and chair of Pharmacology at Lincoln College, Oxford. She was both an undergraduate and graduate at Oxford. Her multidisciplinary work in biochemical and electrophysiological environments has explored novel neuronal mechanisms involved in areas of the brain affected in both Alzheimer's and Parkinson's diseases. The theme is to arrest neuronal death in these disorders. In 1998 she was awarded the
Michael Faraday medal by the Royal Society and in 1999 was elected honorary FRCP. She is involved in science policy and has given a consultative seminar to the Prime Minister on the future of science in the UK. She was awarded a Life Peerage (a nonpolitical cross bencher) in 2001. Her latest book, Tomorrow's People, touches on a similar background and was published in September 2003.

Editor

has been shown that non-piano players exposed for only five days to learning five-finger piano exercises will show an enhanced territory in the areas of their brains related to the digits than will the so-called controls. More remarkable still is that those who were asked simply to imagine that they were playing the piano showed a similar structural change. I gather the same applies to golf. Apparently if you imagine that you are going to play golf and think about the golf swings, then when finally you go on to the course, you will find that you are more competent than would otherwise be the case.

Those examples shoot down the old dichotomy of mind and brain and show that the most airy of mental events actually does have a physical home among the connections. Not only can we see that this breaks down the barriers of nature and nurture, of mind and brain, and of the physical and mental, but every thought we have, however seemingly insubstantial and refined, has a physical base in the brain. It is therefore important to realise the huge power that the environment will have on our children, and in particular the parents who feature in that environment, because they will quite literally be leaving a mark on the brain.

\section{Arch Dis Child 2003;88:954-955}

\section{Author's affiliation}

S A Greenfield, Fullerian Professor of Pharmacology, Lincoln College, Oxford, UK

Correspondence to: Dr N P Mann, Dept of Paediatrics, Royal Berkshire Hospital, London Road, Reading RGI 5AN, UK; npmann2@aol.com

\section{ARCHIVIST}

\section{Melanocortin 4 receptors and obesity}

$\mathrm{S}$ ince all obesity results from an excess of energy intake over energy expenditure it follows that too much food and too little exercise must underlie the current obesity pandemic. It is tempting to blame fast food, cars, and television, and no doubt they share a lot of the blame, but could some people affected by modern lifestyle changes be genetically predisposed to succumb? Or have the genetic syndromes always existed and are they irrelevant to the recent increase?

Leptin is produced by adipocytes and stimulates production of proopiomelanocortin in the arcuate nucleus of the hypothalamus. Proopiomelanocortin is degraded by prohormone convertases to $\alpha$ melanocyte-stimulating hormone that acts via hypothalamic melanocortin 4 receptors (MC4Rs) to reduce appetite. It has been estimated that gene mutations in this system could account for between $0.5 \%$ and $4 \%$ of cases of obesity, but researchers in Cambridge (I Sadaf Farooqi and colleagues. New England Journal of Medicine 2003;348:108595; see also editorial, ibid: 1160-3) have found MC4R gene mutations in almost $6 \%$ of 500 people with severe obesity (mean standard deviation score for body mass index 4.2) beginning before the age of 10 years.

Nucleotide sequencing of the MC4R gene in the 500 unrelated probands showed mutations in 29, 23 heterozygotes and six homozygotes. These mutations were absent from 100 alleles of non-obese people. Family studies showed codominant inheritance. All relatives of heterozygous probands who had the mutation also had early onset obesity. Among the families of homozygous probands all 12 homozygotes, but only 17 of 25 heterozygotes, had early onset obesity. Homozygotes in these families were more obese than heterozygotes. The phenotype included severe early onset obesity, increased lean mass (greater than in leptin deficiency), increased growth in height, hyperphagia, severe hyperinsulinaemia, and increased bone density. Hyperinsulinaemia and hyperphagia tended to decrease in late childhood and early adult life. Analysis of gene function in cell cultures showed that residual function was associated with less severe phenotype.

In another paper in the same issue of the New England Journal of Medicine (ibid: 1096-103) researchers in Switzerland and Germany report binge eating in all of 20 subjects with severe obesity and an MC4R mutation, but in only 17 of 120 similarly obese subjects without an $M C 4 R$ mutation. Leptin receptor mutations were not associated with binge eating.

Genetic causes of obesity are being delineated increasingly. What contribution, if any, this knowledge has made to understanding the worldwide increase in obesity seems uncertain. The hope, though, must be that it may lead to new approaches to treatment. 